\title{
Revision of the Iteaphila setosa group (Diptera: Empididae)
}

\author{
IGOR V. SHAMSHEV ${ }^{1}$ and BRADLEY J. SINCLAIR ${ }^{2}$ \\ ${ }^{1}$ All-Russian Institute of Plant Protection, Podbelskogo 3, Pushkin, St. Petersburg 189620, Russia; e-mail: shamshev@mail.ru \\ ${ }^{2}$ Ottawa Plant \& Seed Laboratories - Entomology, Canadian Food Inspection Agency, K.W. Neatby Bldg., C.E.F., 960 Carling Ave., \\ Ottawa, ON, Canada K1A 0C6; e-mail: bradley.sinclair@inspection.gc.ca
}

Key words. Iteaphila, Empidoidea, Empididae, taxonomy, new species, distribution

Abstract. Six species are identified in the Iteaphila setosa group [I. arundela sp. n., I. caucasica sp. n., I. italica Loew, 1873, I. kubaniensis sp. n., I. merzi sp. n., I. setosa (Bezzi, 1924)]. This species group is distributed from southern England in the west, through southern Europe and northern Africa, to the Caucasus and Middle Asia (Uzbekistan).

\section{INTRODUCTION}

At higher northern latitudes and montane regions, the genus Iteaphila Zetterstedt, 1838 is one of the first pollinators active in early spring, primarily visiting flowers of Prunus and Salix and other spring flowers. Apart from these collection records, little is known about the biology of Iteaphila. There are currently some 19 recognized species of Iteaphila (Shamshev \& Sinclair, unpubl. data), including at least two Holarctic species (I. nitidula Zetterstedt, 1838, I. macquarti Zetterstedt, 1838). Iteaphila includes quite small (about $3.0 \mathrm{~mm}$ ) blackish grey flies with long antennae, conspicuously lengthened proboscis and palpi (which are usually directed forward and subequal in length), slender legs and humped thorax clothed in numerous unmodified hair-like setae. Iteaphila is a primitive empidoid taxon currently unassigned to family in the Empidoidea (Sinclair \& Cumming 2006) (see Discussion section below).

Ragas setosa Bezzi, 1924 was transferred to Iteaphila by Sinclair \& Saigusa (2001), highlighting an odd species with modified male hind femur, shortened, tapered antennae, and male terminalia with a distinct surstylus and epandrial lobe. During a revision of the entire Iteaphila group we discovered that I. setosa represented a distinct species group and also included I. italica Loew, 1873. Tuomikoski (1958) questioned whether I. italica Loew was congeneric given the shape of the antenna and male terminalia as illustrated in Engel (1941) and the southern distribution of this otherwise northern or montane genus. We prefer to retain this group within Iteaphila until a thorough revision and phylogenetic analysis is completed for the entire Iteaphila group. This is the first of several revisions on this genus group and describes five additional species related to I. setosa.

\section{MATERIAL AND METHODS}

This study is based on material borrowed from or deposited in the following collections: M. Barták collection [private], Prague, Czech Republic (BARC); British Entomological and Natural History Society (BENH); The Natural History Museum,
London, England (BMNH); Canadian National Collection of Insects, Ottawa, Canada (CNC); Peter Hodge collection [private], Lewes, England (DODC); Museo Civico di Storia Naturale, Milan, Italy (MSNM); Muséum d'Histoire Naturelle, Geneva, Switzerland (MHNG); National Museum of Ireland, Dublin, Ireland (NMID); National Museum of Scotland, Edinburgh, Scotland (NMSE); National Museum of Wales, Cardiff, UK (NMWC); Oxford University Museum of Natural History, Oxford, England (OUMNH); World Museum of Liverpool, Liverpool, England (WML); United States National Museum of Natural History, Washington, DC, USA (USNM); Zoological Institute, St. Petersburg, Russia (ZIN); Museum für Naturkunde der Humboldt-Universität zu Berlin, Berlin, Germany (ZMHB); Zoological Museum of Moscow State University, Moscow, Russia (ZMUM).

All dissections were made in glycerine and tissues cleared using hot $85 \%$ lactic acid. Terms used for adult structures primarily follow those of McAlpine (1981), except for antennal morphology which follows Stuckenberg (1999) and for the wing venation where the terms of Saigusa (2006) are used. Consequently the following wing venation terms are used: $\mathrm{M}_{4}$ (= $\left.\mathrm{CuA}_{1}\right)$, cell cua $(=$ anal cell or cell cup $)$, and $\mathrm{CuA}+\mathrm{CuP}(=$ anal vein or $\mathrm{A}_{1}$ ). Homologies of the male terminalia follow those of Sinclair \& Cumming (2006).

Label data for primary types are cited in full, where labels are listed from the top downward, with data from each label enclosed in quotation marks. Labels are cited with original spelling, punctuation and date and lines are delimited by a slash mark (/). Additional information is included in square brackets. The repository of each type is given in parentheses. The following abbreviations are used in the descriptions: dc - dorsocentral bristle, pprn - postpronotal bristle, presut spal - presutural supra-alar bristle, npl - notopleural bristle, pal - postalar bristle, psut spal - postsutural supra-alar bristle, and sctl - scutellar bristle.

\section{ITEAPHILA SETOSA SPECIES GROUP}

\section{Recognition}

The species group is distinguished by the following combination of characters: postpedicel with broad base, with apical half tapered; stylus nearly half length of pedicel; apical mechanoreceptor (bristle) greatly reduced in length; scutellum with 2-3 pairs of apical bristles; male 
hind femur usually modified; wing with basal costal bristle present; cell $\mathrm{dm}$ produced apically; male terminalia with epandrial lobe and surstylus distinctly digitiform.

\section{Key to species of the Iteaphila setosa species group}

1 Antennal stylus long, nearly half length of postpedicel, lacking apical mechanoreceptor (bristle). Scutellum with 2-3 pairs of bristles. Basal costal bristle present. Epandrial lamella with additional lobe [I. setosa group]. . . . . . . 2

- Antennal stylus very short relative to length of postpedicel, with apical mechanoreceptor (bristle). Scutellum with at least 4 pairs of bristles. Basal costal bristle absent. Epandrial lamella lacking additional lobe.

. . . macquarti group, not treated herein]

2 Male (holoptic)....................... 3

- Female (dichoptic) (unknown for I. setosa, I. caucasica, and I. kubaniensis). . . . . . . . . . . . . . . . . .8

3 Hind femur unmodified. Epandrial lobe sinuous, slender, nearly twice length of surstylus and strongly arched medially (Fig. 3) . . . . . . . . . . . . . . . . . . . . . . . I. italica

Hind femur modified, with deep, broad, ventral constriction basally (Fig. 7). Epandrial lobe similar in length to surstylus ......................... 4

4 Hind femur with scattered setulae near base, lacking flattened bristles. Surstylus slender and finger-like (Figs 1, 2, 4,

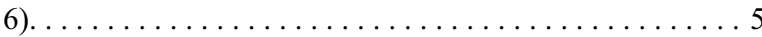
Hind femur with tuft of several flattened, curved long bristles near base (Fig. 7). Surstylus broad, thumb-like and highly setose (Fig. 5). . . . . . . . . . . I. merzi sp. n.

5 Halter knob pale. Gonocoxal apodeme very short, less than one-third length of ejaculatory apodeme (Fig. 4); hypandrium with deep and broad notch. ..... I. kubaniensis sp. n. - Halter knob dark. Gonocoxal apodeme broad and greater than one-half length of ejaculatory apodeme; hypandrium with shallow or deep notch (Figs 1,2,6).........6

6 Legs dark. Ventral margin of epandrial lobe uneven, sculptured, apex narrower than base of lobe (Fig. 6). . . I. I. setosa

- Legs with "knees" pale. Ventral margin of epandrial lobe smoothly curved, apex slightly expanded and broadly rounded. ......................... 7

7 Fore tibia with posterodorsal setae nearly twice width of tibia. Hypandrium with shallow notch; apex of surstylus broadly rounded (Fig. 1). . . . . . . I. arundela $\mathrm{sp.}$. - Fore tibia lacking long posterodorsal setae. Hypandrium with deep and broad notch; apex of surstylus somewhat pointed (Fig. 2) . . . . . . . . . . . I. caucasica $\mathrm{sp.} \mathrm{n.}$

8 Halter brownish . . . . . . . . . . . . . . . . . Italica

- Halter yellow . . . . . . . . . . . . . . . . . . . . . . . 9

9 Legs uniformly dark, acrostichals biserial .... I. merzi sp. n.

- Legs with "knees" yellow, acrostichals 2-4-serial anteriorly $\ldots \ldots \ldots \ldots \ldots \ldots \ldots$. . arundela sp. n.

\section{Iteaphila arundela sp. $\mathrm{n}$.}

(Figs 1, 8)

Recognition. This species is readily distinguished from other species of this group by the pale knees, 2-4-serial acrostichals in females, pale female halter, and basal constriction of the male hind femur, lacking modified setae.

Description. Wing length $2.7-3.0 \mathrm{~mm}$.

Male. Head black, with black setation; occiput finely greyish brown pollinose. Eyes holoptic, with upper ommatidia enlarged. Frons represented by small triangular space just above antennae, bare, brownish pollinose. Ocellar triangle very prominent with 2 pairs of bristles; anterior ocellars moderately long, proclinate and lateroclinate, posterior ocellars short. Postvertical and postocular bristles quite strong, longer than ocellars; additionally, occiput covered with numerous similar setae of different lengths on lower part. Antenna black; scape short, subequal to globular pedicel, both with short setae; postpedicel rather broad at base, about 2.0 times longer than basal width, strongly tapered; stylus about $1 / 2$ of postpedicel length; segment 9 nearly 4 times as long as wide, apical sensillum inconspicuous. Proboscis long, projected obliquely; labium about as long as head height; palpus projected parallel to labrum, about two-thirds length of labrum.

Thorax black in ground colour, with black setation; scutum viewed dorsally matt black brown, with 2 hardly prominent paler vittae between acrostichal and dorsocentral bristles, viewed anteriorly pale vittae between acrostichal and dorsocentral bristles; mesopleuron uniformly brownish grey pollinose. Proepisternum with 2-3 short brownish setae on lower part and 1 long seta on upper part. Postpronotal lobe with 1 long and 3-4 short pprn. Mesonotal bristles prominent; acrostichals biserial, somewhat irregular, slightly shorter than dc, lacking on prescutellar depression; dc uniserial, offset from row anteriorly, 1 pair anteriorly and 2 prescutellar pairs long; 1 posthumeral, 1-2 presut spal, 3 strong and 3 thinner npl, 3-4 short psut spal, 1 pal, 2 pairs of sctl.

Legs brownish, knees of fore and mid legs brownish yellow, finely greyish pollinose. Coxae and trochanters with rather long, black, unmodified setae. Fore and mid femora with row of moderately long (about as long as femur deep), uniform posteroventral setae. Fore and mid tibiae with some prominent posterodorsal setae. Hind femur with deep broad excision near base, anterior margin of excision not strongly produced, with row of moderately long anteroventral and posteroventral setae. Hind tibia with erect, dorsal setae of different lengths (shorter setae as long as tibia is deep). Fifth tarsomere on all legs flattened; pulvilli broad, shorter than tarsal claw.

Wings finely infuscate, in some views iridescent on anal lobe, with brownish veins; 1 moderately long black seta at wing base; stigma distinct, brownish yellow, elliptical, overlapping apex of vein $\mathrm{R}_{1}$; anal lobe very prominent, acute. Sc complete; $\mathrm{R}_{2+3}$ straight in apical part; radial fork present, $\mathrm{V}$-shaped with its base before apex of vein $\mathrm{R}_{2+3}$; veins $\mathrm{R}_{5}$ and $\mathrm{M}_{1}$ nearly parallel before wing-apex; cell $\mathrm{dm}$ broad, longer than basal cells, produced apically; $\mathrm{m}-\mathrm{m}$ crossvein long, $\mathrm{M}$ branches widely separated; distance between apices of veins $\mathrm{R}_{2+3}$ and $\mathrm{R}_{4}$ shorter than that between veins $\mathrm{R}_{4}$ and $\mathrm{R}_{5}$; dm-cu crossvein slightly concave; $\mathrm{M}_{4}$ somewhat longer than dm-cu crossvein. Apex of cell cua (= anal cell) slightly rounded, $\mathrm{CuA}+\mathrm{CuP}(=$ anal vein) long, ending just short of wing margin. Halter brownish.

Terminalia (Fig. 1) concolorous with abdomen, small. Hypandrium subtriangular, with lower distinct notch and upper sharply pointed notch basal to apical prolongation into pair of recurved hook-like lobes; apex of lobes rounded; gonocoxal apodemes longer than broad, slightly 


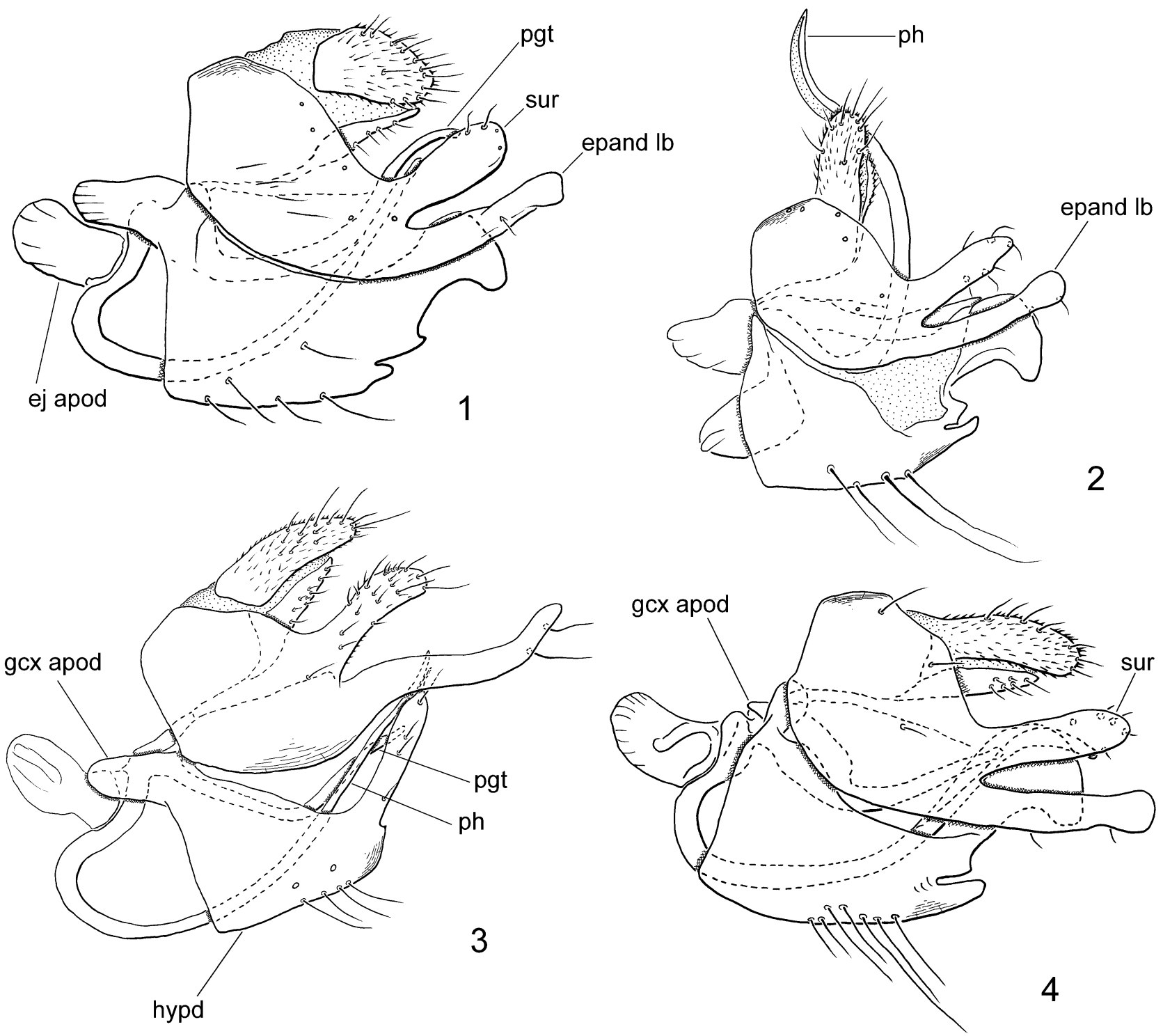

Figs 1-4: Iteaphila setosa group, male terminalia, lateral view: 1 - I. arundela; 2 - I. cancasica; 3 - I. italica; 4 -I. kubaniensis. Abbreviations: ej apod - ejaculatory apodeme; epand lb - epandrial lobe; gcx apod - gonocoxal apodeme; hypd - hypandrium; pgt postgonite; ph - phallus; sur - surstylus.

shorter than ejaculatory apodeme; postgonite longer and slender, sickle-shaped, slightly downwardly curved apically. Phallus slender, strongly arched with apex straight; ejaculatory apodeme laterally flattened, apex rounded. Epandrium with broad dorsal bridge; epandrial lobe slightly longer than surstylus, apex expanded and incurved. Surstylus slender finger-like, expanded apically and straight, inner surface with stout setae; lacking inner projecting lobe. Cercus broad, apex tapered and rounded with long marginal setae; hypoproct well developed, apex broad, bearing setae.

Female. Head with shorter and sparser setation than male; occiput, ocellar tubercle and frons densely brownish grey pollinose. Eyes dichoptic, ommatidia equally small. Frons very broad, with stout marginal setulae and one interfrontal pair. Scutum viewed dorsally or anteriorly whitish-grey pollinose; acrostichals 2-4-serial anteriorly. Femora and tibiae with short setae (except subapicals); femora with pale knees. Halter pale, yellow. Abdomen densely greyish pollinose, with short brownish yellow to brownish setation. Cercus brownish, rather short.

Type material. Holotype, male labelled: "ENGLAND / West Sussex / Arundel Park, TQ005108 / On Mercurialis perennis / growing under beech trees / 1.v.1988 P.J. Hodge / 2248 [underside of label]"; "HOLOTYPE / Iteaphila / arundela / Shamshev \& Sinclair [red label]" (BMNH). Paratypes: ENGLAND. Same data as holotype, on Acer campestre flowers, 2.-3.v.1990,

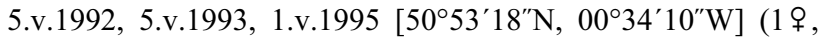
BENH [4022]; 3, BMNH [4027, 4783-4]; 2q, CNC [3178-9]; 9 DODC $[3173,3176,4023-4025,4185$, 4780-4782]; 1, NMID [4026]; 19 , NMSE [4184]; 19 , NMWC [3177]; 1 9, OUMNH [4186]; 2q, USNM [3174, 4187]; 1 9 , WML [4779]); Wychwood Forest, Oxon, SP3445 [52 $\left.06^{\prime} 24^{\prime \prime} \mathrm{N}, 01^{\circ} 29^{\prime} 52^{\prime \prime W}\right]$, 6.iv.-4.v.1990, MT, K. Porter; det. R. Crossley ( $1 \hat{\jmath}$, in alc., NMWC).

Etymology. The epithet refers to the type locality where the first specimens were collected.

Distribution. Europe: England (Fig. 8). 

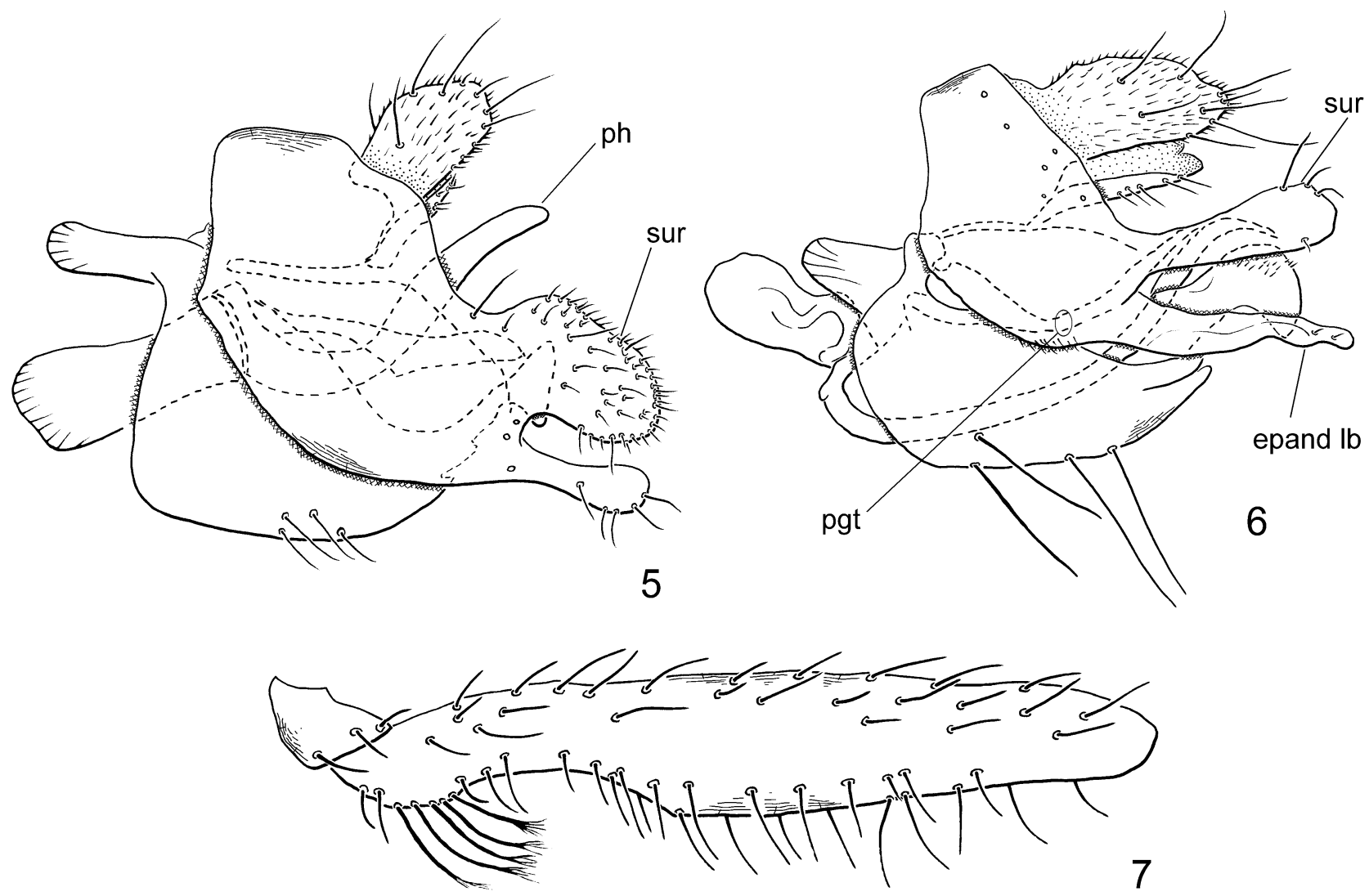

Figs 5-7: Iteaphila setosa group. 5 - I. merzi, male terminalia, lateral view; 6 - I. setosa, male terminalia, lateral view; 7 - I. merzi, male hind femur, posterior view. Abbreviations: epand lb - epandrial lobe; pgt - postgonite; ph - phallus; sur - surstylus.

Remarks. The occurrence of Iteaphila in England was first reported by Chandler (1998) and the specimens upon which this record was based were examined in the present study. An additional single female specimen was collected 6 May 2009 by Peter Chandler, swept from maple blossoms (P. Chandler, pers. comm. 2009).

Arundel Park is an old deer park (deer removed half a century ago) well known for its dead wood fauna (mainly Coleoptera) associated with the ancient beech trees (Fagus sylvatica). The site where Iteaphila has been recorded consists of a small area of mixed beech/ash (Fraxinus excelsior) woodland adjacent to ungrazed chalk grassland with developing scrub consisting of hawthorn (Crataegus sp.), field maple (Acer campestre) and sycamore (Acer pseudoplatanus) in a dry east facing valley. The ground flora at this site is dominated by dog's mercury (Mercurealis perennis).

\section{Iteaphila caucasica sp. $\mathbf{n}$.}

(Figs 2, 8)

Recognition. This species is most similar to I. kubaniensis distinguished from the latter species by the dark male halter knob, apically pointed surstylus, and large gonocoxal apodemes.

Description. Wing length $2.2 \mathrm{~mm}$.

Male. Head black, with black setation; occiput finely greyish brown pollinose. Eyes holoptic, with upper ommatidia enlarged. Frons represented by small triangular space just above antennae, bare, brownish pollinose.
Ocellar triangle very prominent with 2 pairs of bristles; anterior ocellars moderately long, proclinate and lateroclinate, posterior ocellars short. Postvertical and postocular bristles quite strong, longer than ocellars; additionally, occiput covered with numerous similar setae of different lengths on lower part. Antenna black; scape short, subequal to globular pedicel, both with short setae; postpedicel rather broad at base, about 2.0 times longer than basal width, strongly tapered on apical half; stylus subequal to length of postpedicel; apical sensillum inconspicuous. Proboscis projected obliquely, retracted into head (components not able to assess).

Thorax brown in ground colour, with black setation; scutum viewed dorsally matt black brown, with 2 hardly prominent paler vittae between acrostichal and dorsocentral bristles, viewed anteriorly; mesopleuron uniformly brownish grey pollinose. Proepisternum obscured due to mounting. Postpronotal lobe with 1 long and 1-2 short pprn. Mesonotal bristles short and stout; acrostichals 4-serial, somewhat irregular, slightly shorter than dc, lacking on prescutellar depression; dc uniserial, offset from row anteriorly, 2 prescutellar pairs long; 1 posthumeral, 1-2 presut spal, 3 strong npl, 3-4 short psut spal, 1 pal, 2 pairs of sctl.

Legs generally brownish, knees and tibiae distinctly paler, finely greyish pollinose. Coxae and trochanters with rather long, black, unmodified setae. Fore and mid femora with row of uniformly moderately long posteroventral setae (about as long as femur deep). Fore tibia 


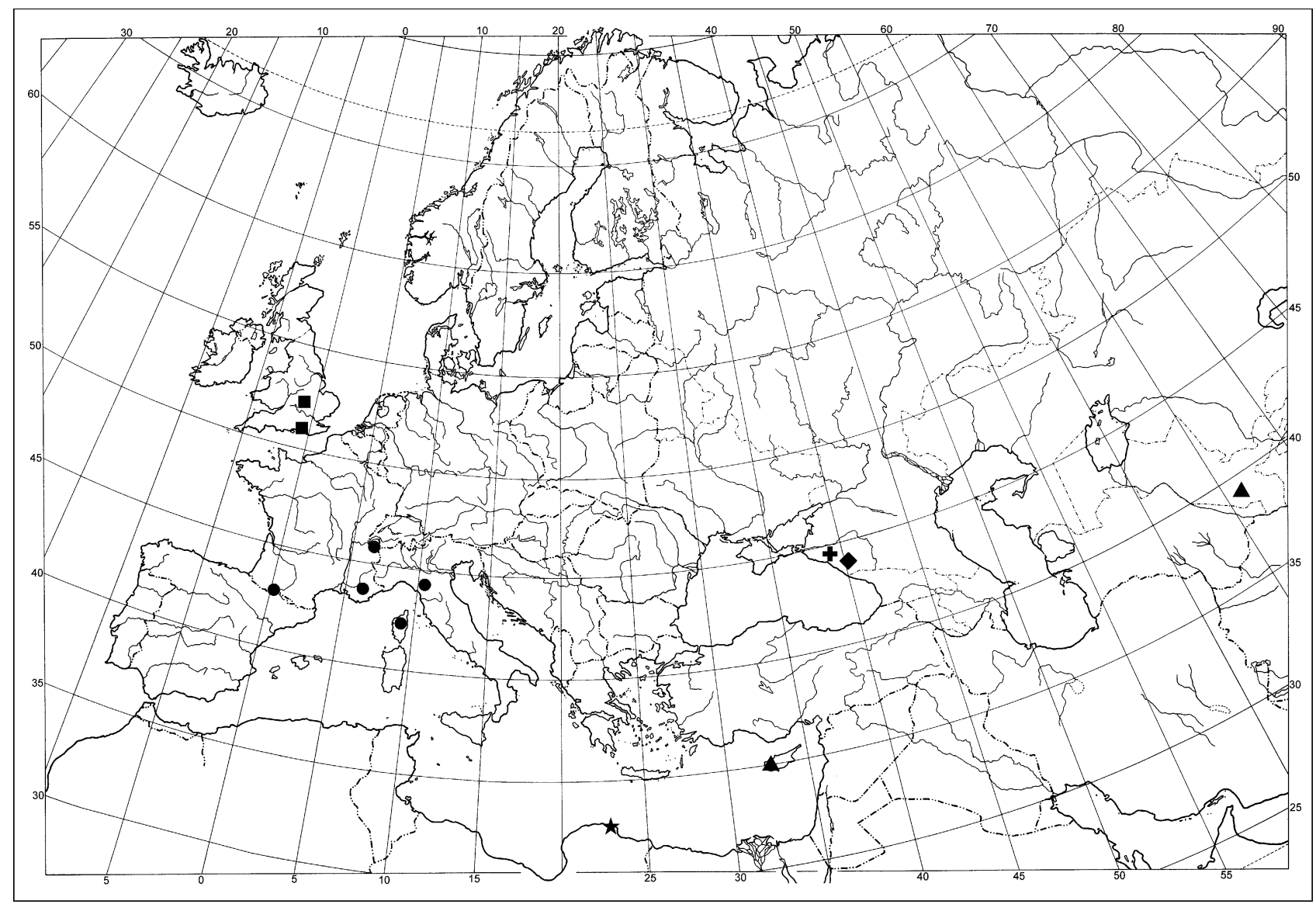

Fig. 8. Distribution of Iteaphila setosa group. Abbreviations: $\Delta-I$. merzi; $\star-I$. setosa.

lacking prominent posterodorsal setae. Hind femur with broad constriction on basal third, anterior margin of constriction not strongly produced, with row of moderately long anteroventral and posteroventral setae. Hind tibia with erect dorsal setae of different lengths (shorter setae as long as tibia is deep). Fifth tarsomere on all legs flattened; pulvilli broad, shorter than tarsal claw.

Wings finely infuscate, with brownish veins; 1 moderately long black seta at wing base; stigma distinct, brownish yellow, elliptical, overlapping apex of vein $R_{1}$; anal lobe very prominent, acute. Sc complete; $\mathrm{R}_{2+3}$ straight in apical part; radial fork present, $\mathrm{V}$-shaped with its base before apex of vein $R_{2+3}$; veins $R_{5}$ and $M_{1}$ nearly parallel before wing-apex; cell $\mathrm{dm}$ broad, longer than basal cells, produced apically; $\mathrm{m}-\mathrm{m}$ crossvein long, $\mathrm{M}$ branches widely separated; distance between apices of veins $R_{2+3}$ and $\mathrm{R}_{4}$ shorter than that between veins $\mathrm{R}_{4}$ and $\mathrm{R}_{5} ; \mathrm{dm}$-cu crossvein slightly concave; $\mathrm{M}_{4}$ somewhat longer than $\mathrm{dm}$-cu crossvein. Apex of cell cua (= anal cell) slightly rounded, view of $\mathrm{CuA}+\mathrm{CuP}(=$ anal vein) obscured. Halter base and stem pale, knob dark.

Terminalia (Fig. 2) concolorous with abdomen, small. Hypandrium subtriangular, with deep notch basal to apical prolongation into pair of broad hook-like lobes; apex of lobes pointed downwards and closely associated with apex of phallus; gonocoxal apodemes rounded apically, subequal in size to ejaculatory apodeme; postgonite short and slender, sickle-shaped. Phallus slender, strongly arched with apex nearly curved at right angles; ejaculatory apodeme laterally flattened, apex rounded and upwardly curved. Epandrium with broad dorsal bridge; epandrial lobe slightly longer than surstylus, evenly tapered with broad rounded apex; apex incurved. Surstylus slender finger-like, not expanded apically, with setae on inner surface; apex somewhat pointed with ventral margin slightly concave. Cercus broad, apex tapered and rounded with long marginal setae; hypoproct well developed, apex broad, bearing setae.

Female. Unknown.

Type material. Holotype, male labelled: "RUSSIA [in Cyrillic]. Caucasus, glade Guzeripl, middle current of Belaya River, 19.07.1935, leg. Deev"; "HOLOTYPE / Iteaphila / caucasica / Shamshev \& Sinclair [red label]" (ZIN).

Etymology. The epithet refers to the region where the holotype specimen was collected.

Distribution. Europe: North Caucasus (Russia, Adygea) (Fig. 8).

\section{Iteaphila italica Loew, 1873}

(Figs 3, 8)

Iteaphila italica Loew, 1873: 216.

Recognition. This species is readily distinguished from other species of this group by the unmodified male hind femur; epandrial lobe sinuous, slender, nearly twice 
length of surstylus; dark legs in both sexes and dark female halter.

Description. Wing length $2.6-2.8 \mathrm{~mm}$.

Male. Head black, with black setation; occiput finely greyish brown pollinose. Eyes holoptic, with upper ommatidia enlarged. Frons represented by small triangular space just above antennae, bare, brownish pollinose. Ocellar triangle very prominent with 2 pairs of bristles; anterior ocellars moderately long, proclinate and lateroclinate, posterior ocellars minute. Postvertical and postocular bristles rather long, quite strong; additionally, occiput covered with numerous similar setae of different lengths on lower part. Antenna black; scape short, subequal to globular pedicel, both with short setae; postpedicel rather broad at base, about 2.0 times longer than basal width, strongly tapered; stylus about $1 / 2$ of postpedicel length; segment 9 nearly 4.5 times as long as wide, apical sensillum inconspicuous. Proboscis long, projected obliquely; labium about as long as head height; palpus projected parallel to labrum, about two-thirds length of labrum.

Thorax black in ground colour, with black setation; scutum viewed dorsally matt black brown, with 2 hardly prominent paler vittae between acrostichal and dorsocentral bristles, viewed anteriorly appearing densely brown pollinose; mesopleuron uniformly brownish grey pollinose. Proepisternum with 2-3 short brownish setae on lower part and 1 long seta on upper part. Postpronotal lobe with 1 long and 1-2 short pprn. Mesonotal bristles prominent; acrostichals arranged in 2 broad, irregular rows, short, lacking on prescutellar depression; dc uniserial, offset from row anteriorly, mostly subequal in length to acrostichals, 1 pair anteriorly and 2 prescutellar pairs long; 1 posthumeral, 1-2 presut spal, $3 \mathrm{npl}, 2-3$ short psut spal, 1 pal, 2 pairs of sctl.

Legs entirely brownish (sometimes knees of fore and mid legs brownish yellow), finely greyish pollinose. Coxae and trochanters with rather long, black, unmodified setae. Fore and mid femora with row of moderately long (about as long as femur deep), uniform posteroventral setae. Fore and mid tibiae with some hardly prominent posterodorsal setae (1 subbasal seta longer). Hind femur unmodified, with row of moderately long anteroventral and dorsal setae and short, thin posteroventral setae. Hind tibia with erect, dorsal setae of different lengths (shorter setae as long as tibia is deep). Fifth tarsomere on all legs flattened; pulvilli broad, shorter than tarsal claw.

Wings finely infuscate, in some views iridescent on anal lobe, with brownish veins; 1 moderately long black seta at wing base; stigma distinct, brownish yellow, elliptical, overlapping apex of vein $\mathrm{R}_{1}$; anal lobe very prominent, acute. Sc complete; $\mathrm{R}_{2+3}$ straight in apical part; radial fork present, $\mathrm{V}$-shaped with its base before apex of vein $\mathrm{R}_{2+3}$; veins $\mathrm{R}_{5}$ and $\mathrm{M}_{1}$ parallel before wing-apex; cell $\mathrm{dm}$ broad, longer than basal cells, produced apically; m-m crossvein long, $\mathrm{M}$ branches widely separated; distance between apices of veins $R_{2+3}$ and $R_{4}$ shorter than that between veins $\mathrm{R}_{4}$ and $\mathrm{R}_{5}$; dm-cu crossvein slightly con- cave; $\mathrm{M}_{4}$ somewhat longer than dm-cu crossvein. Apex of cell cua (= anal cell) slightly rounded, $\mathrm{CuA}+\mathrm{CuP}(=$ anal vein) long, ending just short of wing margin. Halter brownish.

Abdomen dark brown, viewed dorsally subshining, finely greyish brown pollinose; covered with numerous, brownish yellow, moderately long setae, longer posteriorly. Terminalia (Fig. 3) concolorous with abdomen, small. Hypandrium subtriangular, with small shallow notch basal to apical prolongation into pair of finger-like lobes; apex of lobes pointed and closely associated with apex of phallus; gonocoxal apodemes longer than broad, shorter than ejaculatory apodeme; postgonite longer and slender, sickle-shaped, encircling subapex of phallus. Phallus slender, strongly arched with apex straight; ejaculatory apodeme laterally flattened, apex rounded. Epandrium with broad dorsal bridge; epandrial lobe nearly twice length of surstylus, sinuous and arched medially. Surstylus slender finger-like, expanded apically and slightly downcurved, clothed with fine setae on outer and inner surfaces; inner apex with densely setose, inner directed triangular lobe. Cercus broad, apex tapered and rounded with long marginal setae; hypoproct well developed, apex broad, bearing setae.

Female. Head with shorter and sparser setation than male; occiput, ocellar tubercle and frons densely brownish grey pollinose. Eyes dichoptic, ommatidia equally small. Frons very broad, with stout marginal setulae. Scutum viewed dorsally or anteriorly greyish brown pollinose. Femora and tibiae with short setae (except subapicals). Abdomen densely greyish pollinose, with short brownish yellow to brownish setation. Cercus brownish, rather short.

Type material examined. Holotype, female labelled: "[very small purple rectangular label]"; "10559"; "Holotypus [red]"; "Zool. Mus. Berlin" (ZMHB).

Additional material examined. FRANCE. Corsica, V, 54833 [Iteaphila italica Lw., det. Becker] (1 0,1 ㅇ, ZMHB); same data as previous without Becker's identification label (10, 1 , ZMHB); B-d-R, 630-750 m, Mtes St. Victories, Col des Portes, 4.vi.1995, B. Merz \& Eggenberger leg, Iteaphila? italica Loew, det. B. Merz '97 (1 9, MNHG); Haute-Savoie (74), Pormenaz, 1700-2200 m, 8.-31.vii.2003, MT A, Castella \& Speight leg. (1이 MHNG); Pic Long, along brook, 42.49N, 0.09E, 1800 m, 9.vii.1990, M. Barták (1 +, BARC); Var, Gorges du Verdon, Pont de l'Artuby, 17.v.-13.vi.2003 / MT, Castella \& Speight (2ð, 2 \% , MHNG; $10, \mathrm{CNC})$; Var, Gorges du Verdon, Pont de l'Artuby, 730 m, 17.-19.v.2003, Castella \& Speight (2ઠ, 3 \& , MHNG). ITALY. Toscana, 1400-1600 m, Orecchiella (6 km E Sillano), 29.vi.2000, B. Merz \& F. Mason (1 $\delta^{\dagger}, 1$ ㅇ, MHNG).

Distribution. Europe: Italy, France (including Corsica) (Fig. 8).

Remarks. Loew (1873) described this species from a single female and stated the type locality was "Lucca (Haliday [leg.])" (Italy). Currently, the holotype is in poor condition but the abdomen and postpedicel of both antennae are missing (abdomen destroyed by dermestids). In addition the minuten pin is heavily corroded and unfortunately (or fortunately) broke off while on loan to us. 
The specimen was subsequently glued to the mounting card.

Engel (1941: 196) redescribed the male of I. italica based on specimens taken by Th. Becker from Corsica as noted under "Additional material examined".

The Col des Portes (France) locality is dominated by maquis vegetation, on a very exposed mountain chain with very little vegetation (B. Merz, pers. comm. 2009). In Italy, the nature reserve "Orecchiella" (Lucca province) is wooded mainly with Fagus silvatica L. and open pasture (F. Mason, pers. comm. 2009) and the specific area sampled was the Pania di Corfino nature reserve (Cerretti et al., 2003, p. 16).

\section{Iteaphila kubaniensis sp. $\mathbf{n}$.}

(Figs 4, 8)

Recognition. This species is readily distinguished from other species of this group by the pale male halter, deep hypandrial notch, and basal constriction of the male hind femur, lacking modified setae.

Description. Wing length $2.3 \mathrm{~mm}$.

Male. Head black, with black setation; occiput finely greyish brown pollinose. Eyes holoptic, with upper ommatidia enlarged. Frons represented by small triangular space just above antennae, bare, brownish pollinose. Ocellar triangle very prominent with 2 pairs of bristles; anterior ocellars moderately long, proclinate and lateroclinate, posterior ocellars short. Postvertical and postocular bristles quite strong, longer than ocellars; additionally, occiput covered with numerous similar setae of different lengths on lower part. Antenna black; scape short, subequal to globular pedicel, both with short setae; postpedicel rather broad at base, about 2.0 times longer than basal width, strongly tapered; stylus about $1 / 2$ of postpedicel length; segment 9 nearly 4 times as long as wide, apical sensillum inconspicuous. Proboscis long, projected obliquely; labium about as long as head height; palpus projected parallel to labrum, about two-thirds length of labrum.

Thorax black in ground colour, with black setation; scutum viewed dorsally matt black brown, with 2 hardly prominent paler vittae between acrostichal and dorsocentral bristles, viewed anteriorly; mesopleuron uniformly brownish grey pollinose. Proepisternum with 2-3 short brownish setae on lower part and 1 long seta on upper part. Postpronotal lobe with 1 long and 1-2 short pprn. Mesonotal bristles prominent; acrostichals biserial, somewhat irregular, slightly shorter than dc, lacking on prescutellar depression; dc uniserial, offset from row anteriorly, 1 pair anteriorly and 2 prescutellar pairs long; 1 posthumeral, 1-2 presut spal, 3 strong npl, 3-4 short psut spal, 1 pal, 2 pairs of sctl.

Legs brownish (possibly tibiae pale, but specimen is partially teneral and coloration in uncertain), knees of fore and mid legs yellow, finely greyish pollinose. Coxae and trochanters with rather long, black, unmodified setae. Fore and mid femora with row of moderately long (about as long as femur deep), uniform posteroventral setae. Fore tibia lacking prominent posterodorsal setae. Mid tibia with prominent posterodorsal seta near middle and base. Hind femur with deep broad excision near base, anterior margin of excision not strongly produced, with row of moderately long anteroventral and posteroventral setae. Hind tibia with erect, dorsal setae of different lengths (shorter setae as long as tibia is deep). Fifth tarsomere on all legs flattened; pulvilli broad, shorter than tarsal claw.

Wings finely infuscate, in some views iridescent on anal lobe, with brownish veins; 1 moderately long black seta at wing base; stigma distinct, brownish yellow, elliptical, overlapping apex of vein $\mathrm{R}_{1}$; anal lobe very prominent, acute. Sc complete; $\mathrm{R}_{2+3}$ straight in apical part; radial fork present, $\mathrm{V}$-shaped with its base before apex of vein $R_{2+3}$; veins $R_{5}$ and $M_{1}$ nearly parallel before wing-apex; cell $\mathrm{dm}$ broad, longer than basal cells, produced apically; $\mathrm{m}-\mathrm{m}$ crossvein long, $\mathrm{M}$ branches widely separated; distance between apices of veins $R_{2+3}$ and $R_{4}$ shorter than that between veins $\mathrm{R}_{4}$ and $\mathrm{R}_{5}$; dm-cu crossvein slightly concave; $\mathrm{M}_{4}$ somewhat longer than dm-cu crossvein. Apex of cell cua (= anal cell) slightly rounded, $\mathrm{CuA}+\mathrm{CuP}(=$ anal vein) long, ending just short of wing margin. Halter pale.

Terminalia (Fig. 4) concolorous with abdomen, small. Hypandrium subtriangular, with deep notch basal to apical prolongation into pair of broad hook-like lobes; apex of lobes pointed downwards and closely associated with apex of phallus; gonocoxal apodemes pointed apically, very short, only slightly projected beyond hypandrium; postgonite longer and slender, sickle-shaped, encircling subapex of phallus. Phallus slender, strongly arched with apex nearly curved at right angles; ejaculatory apodeme laterally flattened, apex rounded and upwardly curved. Epandrium with broad dorsal bridge; epandrial lobe slightly longer than surstylus, with broad shallow subapical notch; apex incurved. Surstylus slender finger-like, not expanded apically, with setae on inner surface; apex lacking inner lobe. Cercus broad, apex tapered and rounded with long marginal setae; hypoproct well developed, apex broad, bearing setae.

Female. Unknown.

Type material. Holotype, male labelled: "RUSSIA [in Cyrillic]. Krasnodar Territory, vicinity of Severskaya, Ubinskaya, V. Kovalev, 5.6.197"; "HOLOTYPE / Iteaphila / kubaniensis / Shamshev \& Sinclair [red label]" (ZMUM).

Etymology. The epithet refers to the historical name ("Kuban") of the territory where the holotype specimen was collected.

Distribution. Europe: North Caucasus (Russia, Krasnodar Territory) (Fig. 8).

\section{Iteaphila merzi sp. $\mathbf{n}$.}

(Figs 5, 7, 8)

Recognition. This species is readily distinguished from other species of this group by the greatly constricted base of the male hind femur with a basal tuft of flattened curved setae, dark legs in both sexes, surstylus broad, thumb-like and highly setose, and pale female halter.

Description. Wing length $2.4-2.5 \mathrm{~mm}$.

Male. Head black, with black setation; occiput finely greyish brown pollinose. Eyes holoptic, with upper 
ommatidia enlarged. Frons represented by small triangular space just above antennae, bare, greyish pollinose. Ocellar triangle prominent with two pairs of bristles; anterior ocellars long, proclinate and lateroclinate; posterior ocellars short. Postvertical and postocular bristles rather long, quite strong; additionally, occiput covered with numerous similar setae of different lengths on lower part. Antenna black; scape short, subequal to globular pedicel, both with short setae; postpedicel broad at base, nearly 2.5 times longer than wide, strongly tapered; stylus long, nearly 2.0 times shorter than postpedicel, apical sensillum reduced; segment 9 long, about 5.0 times as long as wide. Proboscis long, projected obliquely; labium about as long as head is high; palpus projected parallel to labrum, nearly as long as labrum.

Thorax black, with black setation; scutum viewed dorsally dull black brown, with hardly prominent, narrow, paler vittae between acrostichal and dorsocentral bristles, viewed anteriorly brown pollinose, with 2 more distinct paler vittae between acrostichal and dorsocentral bristles; mesopleuron uniformly brownish grey pollinose. Proepisternum with 1-2 brownish setae in lower part and 2-3 similar setae on upper part. Postpronotal lobe with 1 long pprn and several short setae. Mesonotal bristles prominent; acrostichals biserial, moderately long, slightly shorter than dc, lacking on prescutellar depression; dc uniserial, offset from row anteriorly, in anterior part of subequal length and somewhat longer than acrostichals, 3 prescutellar pairs long; 2 posthumeral, 3 shorter presut spal, 3 strong and 3 thinner npl, row of several psut spal of different lengths, 1 pal, 2-3 pairs of sctl.

Legs almost entirely brownish, finely greyish pollinose; knees of fore and mid legs slightly yellowish. Coxae and trochanters with rather long, black, ordinary bristly hairs. Fore femur with long (somewhat longer than femur is deep) setae on posteroventral, dorsal and posterior faces. Fore tibia with row of several erect dorsal setae longer basally. Mid femur and tibia with similar pattern of setation but setae slightly longer, especially posteroventral setae on mid femur; additionally, mid tibia with 2 long ventral subapical setae. Hind femur (Fig. 7) with deep broad excision near base, anterior margin of excision keel-like produced, posterior margin smooth; with rows of long dorsal, antero- and posteroventral setae, bearing tuft of several flattened, curved, fork-tipped long setae just near base of femur. Hind tibia with numerous, long, erect dorsal setae (somewhat shorter apically) running to hind basitarsus. Fifth tarsomere on all legs flattened; pulvilli broad, shorter than tarsal claw.

Wings largely finely infuscate, slightly milky white on anal lobe, with brownish yellow veins; 1 moderately long black seta at wing base; stigma distinct brownish yellow, elliptical, overlapping apex of vein $\mathrm{R}_{1}$; anal lobe very prominent, acute. Sc complete; $\mathrm{R}_{2+3}$ straight in apical part; radial fork present, $\mathrm{V}$-shaped with its base opposite apex of vein $R_{2+3}$; veins $R_{5}$ and $M_{1}$ somewhat divergent before wing-apex; cell $\mathrm{dm}$ broad, longer than basal cells, produced apically; m-m crossvein long, $\mathrm{M}$ branches widely separated; dm-cu crossvein slightly concave; $\mathrm{M}_{4}$ longer than dm-cu crossvein. Apex of cell cua slightly rounded, $\mathrm{CuA}+\mathrm{CuP}$ long, ending just short of wing margin. Halter dark.

Abdomen dark brown, viewed dorsally dull black brown, finely brown pollinose; covered with numerous, brown, moderately long bristles longer posteriorly. Terminalia (Fig. 5) concolorous with abdomen, small. Hypandrium subtriangular, with pair of small shallow notches basal to apical prolongation into pair of triangularly hooked lobes; gonocoxal apodemes longer than broad, two-thirds length of ejaculatory apodeme; postgonite longer and slender, straight. Phallus slender, strongly arched with slightly downcurved apex; ejaculatory apodeme laterally flattened, apex squarely rounded. Epandrium with broad dorsal bridge; epandrial lobe subequal in length to surstylus, straight, not arched medially. Surstylus broad thumb-like, broadly rounded apically and slightly downcurved, clothed with fine setae on outer and inner surfaces; apex lacking inner projection. Cercus broad, apex tapered and rounded with long marginal setae; hypoproct well developed, apex broad, bearing setae.

Female. Head with shorter and sparser setation than male; occiput, ocellar tubercle and frons densely brownish grey pollinose; occiput covered with pale hairs in lower part. Eyes dichoptic, ommatidia equally small. Frons very broad, with stout marginal setulae. Palpus shorter, with shorter scattered setae. Scutum densely greyish pollinose, viewed dorsally with brownish vittae down acrostichal and dorsocentral bristles. Legs with hardly prominent, short, unmodified setation; fore and mid femora with short posteroventral thin setae longer subapically, hind femur with short anteroventral and dorsal setae. Hind femur unmodified. Wing uniformly finely infuscate. Halter pale, yellow. Abdomen densely greyish pollinose, with short brownish yellow to brownish setation. Cercus brownish, short.

Type material. Holotype, male labelled: "CYPRUS $780 \mathrm{~m} /$ Diarizos valley / 2kmNE Ag.Nikolaos / 25.IV.2002/St. 17"; "34.52N/32.47N [E] / maquis / leg. Merz, Deeming / Ebejer \&

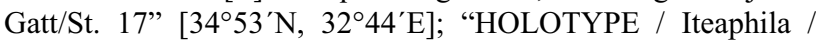
merzi / Shamshev \& Sinclair [red label]" (MHNG). Paratypes: CYPRUS. Same data as holotype (3 $\hat{0}, 14$ \% , MHNG); Kissousa, 27.iv.2002, 34.49N/32.48E, mixed forest stream, Merz, Deeming, Ebejer \& Gatt, St. 23 (1 9, MHNG).

Additional material examined. UZBEKISTAN. Amankutan, pasture, $39.19^{\circ} \mathrm{N}, 66.55^{\circ} \mathrm{E}\left[39^{\circ} 11^{\prime} 24^{\prime \prime} \mathrm{N}, 66^{\circ} 30^{\prime} 0^{\prime \prime} \mathrm{E}\right], 1300 \mathrm{~m}$, 23.v.1989, M. Barták (3 đิ, 1 \% , BARC).

Etymology. The species is named in honour of the dedicated dipterist Bernhard Merz who collected most of the material that this paper is based upon.

Distribution. Asia: Uzbekistan; Europe: Cyprus (Fig. 8).

Remarks. The type series was abundant on various flowers in typical maquis vegetation with tiny shrubs and herbs (B. Merz, pers. comm. 2009).

Although the male hind femur is modified similarly to I. setosa, it is characterized by a tuft of flattened curved setae. The males from Uzbekistan differ somewhat from the Cyprus population, with the surstylus more rounded and slightly shorter. 


\section{Iteaphila setosa (Bezzi, 1924)}

(Figs 6,8)

Rhagas setosa Bezzi, 1924: 14.

Iteaphila setosa: Sinclair \& Saigusa, 2001: 518.

Recognition. This species is readily distinguished from other species of this group by the dark male legs and halter, and basal constriction of the hind femur which lacks modified setae.

\section{Description.}

Male. See Sinclair \& Saigusa (2001: 518) for redescription, except male terminalia redescribed as follows: Terminalia (Fig. 6) concolorous with abdomen, small. Hypandrium subtriangular, with deep notch basal to apical prolongation into pair of recurved hook-like lobes; apex of lobes rounded; gonocoxal apodemes longer than broad, shorter than ejaculatory apodeme; postgonite longer and slender, sickle-shaped, slightly downwardly curved apically. Phallus slender, strongly arched with strongly curved apex; ejaculatory apodeme laterally flattened, apex broadly rounded. Epandrium with broad dorsal bridge; epandrial lobe distinctly longer than surstylus, ventral margin uneven, sculptured, apex slender and incurved. Surstylus slender finger-like, expanded apically and straight, inner surface with stout setae; lacking inner projection. Cercus broad, apex tapered and rounded with long marginal setae; hypoproct well developed, apex broad, bearing setae.

Female. Unknown.

Type material examined. Holotype, male labelled: "Derna / Ciren[aica].(Festa)" [dissected] (MSNM).

Distribution. North Africa: Libya (Fig. 8).

Remarks. The type locality is from Darnah, on the northeast coast of Libya.

The postgonite in the illustrations of the male terminalia of this species in Sinclair \& Saigusa (2001, Figs 27, 28) is mislabelled. The label lines point to the apical lobes of the hypandrium. The true postgonites are the narrow sickle-shaped lobes dorsal to the phallus (see also Fig. 6).

\section{DISCUSSION}

Phylogenetic affinities. The systematic position of Iteaphila has been controversial, having been assigned to the Hybotinae (Collin, 1961), Empidinae (Melander, 1965) and Oreogetoninae (Chvála, 1981). More recently the genus, together with Anthepiscopus Becker, 1891, was assigned to the Iteaphila genus-group, viewed as a very primitive empidoid lineage and currently unassigned to family within the Empidoidea (Sinclair \& Cumming, 2006) or placed as sister group to the remaining Empididae (exclusive of Brachystoma Meigen, 1822) (Moulton \& Wiegmann, 2007, Fig. 1).

Anthepiscopus is distinguishable from Iteaphila only on the basis of the unbranched $\mathrm{R}_{4+5}$, a character that is often subject to aberrant development and homoplasy. Whether these two genera are monophyletic with respect to each other will be examined in planned revisions of this genus group. The presence or absence of the radial fork (i.e., branched $\mathrm{R}_{4+5}$ ) also defines the genera Rhamphomyia
Meigen, 1822 and Empis L., 1758, which are apparently not monophyletic. In addition to addressing the generic limits, future studies will examine the presence of Iteaphila and Anthepiscopus in Baltic amber.

Iteaphila setosa, I. arundela, I. caucasica, I. kubaniensis, and $I$. merzi are assigned to a monophyletic group, defined on the basis of the hook-like apical lobes of the hypandrium. The four former species are most similar on the basis of male terminalia, with I. setosa, I. caucasica, and I. kubaniensis characterized by a deep hypandrial notch.

Biogeography. The Iteaphila setosa group is confined to the Mediterranean Province (Fig. 8). In Diptera, a great diversity of families also exhibits this distribution pattern (see Jong, 1998; Kirk-Spriggs \& McGregor, 2008). Examples among Empidoidea include Nemedina Chandler, 1981, Schistostoma albopilosum group (Shamshev $\&$ Sinclair, 2006), and numerous species of Platypalpus Macquart, 1827 (Grootaert \& Chvála, 1992) and Hilara Meigen, 1822 (Chvála, 2008) are also confined to this region.

ACKNOWLEDGEMENTS. We are indebted to the following curators for the loan of valuable material: M. Chvála and M. Barták (BARC), E. McAlister (BMNH), F. Rigato (MSNM), B. Merz (MHNG), A. Plant (NMWC), J. Ziegler (ZMHB), A. Ozerov (ZMUM). The German Research Foundation (DFG) provided funding to IVS for a research stay to Museum Koenig, Bonn. R. Crossley and P. Hodge kindly provided a series of specimens of Iteaphila from England and the latter assisted in the description of the type locality. P. Chandler and one anonymous reviewer provided some helpful editorial comments.

\section{REFERENCES}

Bezzi M. 1924: Missione del Dr. E. Festa in Cirenaica. XI. Ditteri di Cirenaica. Boll. Mus. Zool. Anat. Comp. R. Univ. Torino (N. S. no. 18) 39[1925]: 1-26.

Cerretti P., Tagliapietra A., Tisato M., Vanin S., Mason F. \& Zapparoli M. (eds) 2003: Artropodi dell'orizzonte del faggio nell'appennino settentrionale Primo contributo. In: Conservazione Habitat Invertebrati 2. Gianluigi Arcari, Mantova, 254 pp.

Chandler P.J. (ed.) 1998: Checklists of insects of the British Isles (New Series). Part 1: Diptera (incorporating a list of Irish Diptera). Handbooks for the Identification of British Insects 12(1): 1-234.

ChvÁla M. 1981: Classification and phylogeny of Empididae, with a presumed origin of Dolichopodidae (Diptera). Entomol. Scand. Suppl. 15: 225-236.

Chvála M. 2008: Monograph of the genus Hilara Meigen (Diptera: Empididae) of the Mediterranean region. Stud. Dipterol. Suppl. 15, 138 pp.

Collin J.E. 1961: Empididae. In British Flies. Vol. 6. Cambridge University Press, Cambridge, $782 \mathrm{pp}$.

Engel E.O. 1941: 28. Empididae (partim). In Lindner E. (ed.): Die Fliegen der Palaearktischen Region IV, 4. E. Schweizerbart'sche Verlagsbuchhandlung, Stuttgart, pp. 193-272, pls 14-20.

Grootaert P. \& ChvÁla M. 1992: Monograph of the genus Platypalpus (Diptera: Empidoidea, Hybotidae) of the Mediterranean region and the Canary Islands. Acta Univ. Carol. (Biol.) 36: 3-226. 
JONG H. DE 1998: In search of historical biogeographic patterns in the western Mediterranean terrestrial fauna. Biol. J. Linn. Soc. 65: 99-164.

Kirk-Spriggs A.H. \& McGregor G. 2008: Disjunctions in the Diptera fauna of the Mediterranean Province and southern Africa and a discussion of biogeographical considerations. Trans. R. Soc. S. Afr. 63: 1-21.

Loew H. 1873: Systematische Beschreibung der bekannten europäischen zweiflügeligen Insecten. Von Johann Wilhelm Meigen. Zehnter Theil oder vierter Supplementband. Beschreibungen europäischer Dipteren. Dritter Band. H.W. Schmidt, Halle, viii +320 pp.

McAlpine J.F. 1981: Morphology and terminology - Adults. [Chapter] 2. In McAlpine J.F., Peterson B.V., Shewell G.E., Teskey H.J., Vockeroth J.R. \& Wood D.M. (eds): Manual of Nearctic Diptera. Vol. 1. Agric. Canada Monogr. 27. Canadian Government Publishing Centre, Hull, pp. 9-63.

Melander A.L. 1928: Diptera, Fam. Empididae. In Wytsman P. (ed.): Genera Insectorum 185 [1927]. Louis DemetVerteneuil, Bruxelles, $434 \mathrm{pp}$.

Moulton J.K. \& Wiegmann B.M. 2007: The phylogenetic relationships of flies in the superfamily Empidoidea (Insecta: Diptera). Mol. Phylogenet. Evol. 43: 701-713.
Saigusa T. 2006: Homology of Wing Venation of Diptera. Unpublished handout distributed at the $6^{\text {th }}$ International Congress of Dipterology, Fukuoka, Japan, 26 pp.

Shamshev I.V. \& Sinclair B.J. 2006: The genus Schistostoma Becker from Southern Africa, with an evaluation of its generic status (Diptera: Dolichopodidae s. lat., Microphorinae). Afr. Invertebr. 47: 335-346.

Sinclair B.J. \& Cumming J.M. 2006: The morphology, higherlevel phylogeny and classification of the Empidoidea (Diptera). Zootaxa 1180: 1-172.

Sinclair B.J. \& Saigusa T. 2001: Revision of the world species of Ragas Walker (Diptera: Empidoidea). Entomol. Sci. 4: 507-522.

Stuckenberg B.R. 1999: Antennal evolution in the Brachycera (Diptera), with a reassessment of terminology relating to the flagellum. Stud. Dipterol. 6: 33-48.

Tuomikoski R. 1958: Mitteilungen über die Empididen (Dipt.) Finnlands. V. Die Gattung Iteaphila Zett. s. str. Ann. Entomol. Fenn. 24: 125-131.

Received May 6, 2009; revised and accepted June 8, 2009 